DOI: $10.17148 / I A R J S E T .2021 .8926$

\title{
STUDENTS’ PERCEPTION TOWARDS ONLINE CLASSES DURING COVID-19 PANDEMIC
}

\author{
GIRIJA C ${ }^{1,}$ Praseetha $\mathbf{P}^{2}$ \\ Assistant Professor in Commerce, M.P.M.M.S.N.Trusts College, Shoranur, Palakkad ${ }^{1}$ \\ Final BBA, M.P.M.M.S.N.Trusts College, Shoranur,Palakkad ${ }^{2}$
}

\begin{abstract}
The COVID 19 has resulted in school shout all across the world. Globally over 1.2 billion children account of the classroom. As a result, education has changed dramatically, with the distinctive rise of E-learning, whereby teaching is undertaken remotely and on digital platforms. Most educational institutions have shifted to online learning platforms to keep academic activities. Online learning has become an effective mechanism, however, technical constraints like the suitability of devices, and bandwidth issues pose serious challenges. The main objectives of the study are to examine the attitude of students towards online learning and to analyze the issues faced by students in online classes. The study includes both primary and secondary data. The data were collected from 80 respondents. Percentage analysis was used for the analysis purpose of this study. The study reveals that connectivity issues, poor teacher-student relationships create stress among students.
\end{abstract}

Keywords:- Students' perception, Online classes, Covid-19, etc.

\section{INTRODUCTION}

The $21^{\text {st }}$ century has brought about a massive change in the world of education. The internet has brought about a paradigm shift in the fundamental way in which learning is done. It has taken learning beyond the hallowed walls of the universities and into the palms of everyone. But how did this radical transformation occur? Though there are numerous examples of the usage of machines and tools in education throughout history, e-learning in the modern sense of the term is a relatively new concept. Slide projectors and television-based classes have been in use since the 1950s. However, one of the first instances of online learning in the world can be traced back to 1960, at the University of Illinois, USA. Though the internet wasn't invented back then, students began learning from computer terminals that were interlinked to form a network.

An online class is a course conducted over the internet it is generally conducted through a learning management system, in which students can view their course syllabus and academic progress, as well as communicate with fellow students and their students their course instructor online education is electronically supported learning that realizes on the internet for teacher/student interaction and the distribution of class materials.

\section{LITERATURE REVIEW}

Raskova octaberlina, Afif ikhwanui Muslim (2020): A study on the topic: "student perspective online learning barriers and alternative using Google classroom during covid-19 pandemic has made many countries adapt on the new situation in the different sector including education. The Indonesian government has decided to adjust the education mode from face-to-face to online meetings using the various learning management system. The researcher implemented a descriptive mixed-method survey design. The result showed that students experienced three barriers during online learning including familiarity of learning, slow net, physical strain, etc.

Kriswanda krishnapatria (2020): A study conducted on the topic: "From lockdown to let down: students perception of E-learning aim the covid-19 outbreak "the research is motivated by the need of exploring the students' perception implementation of two English language subjects in the time of the covid-19 pandemic. The research is descriptive and data were collected through the online questionnaire. The result of the analysis showed that $100 \%$ of students participated in E-learning and $96.4 \%$ have accessibility in online classes. However, only $56 \%$ expressed satisfaction with the implementation of e-learning.

Hasnan Haber(2020): Conducted a study on "Determination of students perceived learning outcome and satisfaction in online learning during the pandemic of covid19."This study aims to examine the determination resulting in student perceived learning outcome and their influence on student satisfaction. The data collected from undergraduate students in both Korea and India to gain across the country .there is no significant difference in student perceived learning outcomes and student satisfaction. The study will be helpful for the education academics to identify the factors which will enhance student learning outcomes and satisfaction levels in online classes during the coronavirus pandemic. 


\section{International Advanced Research Journal in Science, Engineering and Technology}

Vol. 8, Issue 9, September 2021

DOI: 10.17148/IARJSET.2021.8926

Dr. Sonia, Raju Kumar (2020): A study on the topic "student perception towards online classes digitalization of education after covid-19". A survey the main objective of this paper is to find the impact education system. In this study, the researcher aims to explore the student's perspective in online classes. This survey on higher education students in conducted to perceive how many students are satisfied with online technology during the lockdown in the country due to covid-19.

Black, salah black, Sahiba bounchenak Karima yahiooui (2020): "student perception regarding the abrupt transition regard the abrupt transition to online learning during the covid-19 pandemic". The objective of this exploratory study is to investigate the perception of Algerian university students regarding the abrupt transition to online learning aimed at the covid-19 pandemic. The result showed that students have a negative perception of online learning. They are reluctant about this new digital pedagogy and prefer the traditional way of teaching online during the coronavirus pandemic.

\section{SCOPE OF THE STUDY}

The students are subjected to a wide range of pressure because of online classes. Excessive stress and pressure may lead to problems like anxiety and depression. Eliminate stress among students is necessary for their bright future. The scope of the study is to identify the level of stress among students while attending online classes and to make suggestions for dealing with such education stress.

\section{RESEARCH METHODOLOGY}

Both primary and secondary data were used for the study. The primary data were collected by way of a questionnaire and the secondary data were collected from books, newspapers, journals, articles, and websites, etc. The research was descriptive. The Google form is used for collecting data. Convenience sampling is used to select the sample for data collection. The sampling unit is the students of the various educational institutes. The sampling size for the study consisted of 80 students of various Govt. aided and self-financing colleges. Percentage analysis was used for analysis purposes.

\section{The table: 1 Distribution of respondents based on Gender}

\section{DATA ANALYSIS AND INTERPRETATION}

\begin{tabular}{|l|l|l|}
\hline Option & Frequency & Percentage \\
\hline Male & 10 & 12.5 \\
\hline Female & 70 & 87.5 \\
\hline Others & 0 & 0 \\
\hline Total & $\mathbf{8 0}$ & $\mathbf{1 0 0}$ \\
\hline
\end{tabular}

(Source: Primary)

The above table shows that $12.5 \%$ are male students, $87.5 \%$ are female students.

Table: 2 Distribution of respondents based on age.

\begin{tabular}{|l|l|l|}
\hline Category & Frequency & Percentage \\
\hline Below 20 & 57 & 71.25 \\
\hline $20-25$ & 21 & 26.25 \\
\hline $25-30$ & 2 & 2.5 \\
\hline Above 30 & 0 & 0 \\
\hline Total & 80 & 100 \\
\hline
\end{tabular}

(Source: Primary Data)

The above table shows that $71.25 \%$ are below 20 students, $26.25 \%$ are $20-25$ category of students, $2.5 \%$ are $25-30$ category of students.

Table: 3 Distribution of respondents based on current class level.

\begin{tabular}{|l|l|l|}
\hline Category & Frequency & Percentage \\
\hline UG & 72 & 90 \\
\hline PG & 8 & 10 \\
\hline Others & 0 & 0 \\
\hline Total & 80 & 100 \\
\hline
\end{tabular}

Source: (Primary Data)

From the above table, $90 \%$ of students are undergraduate students, $10 \%$ are postgraduate students.

Table:4 Distribution of respondents based on the preferred method of the class.

\begin{tabular}{|l|l|l|}
\hline Category & Frequency & Percentage \\
\hline Office & 70 & 87.5 \\
\hline Online & 10 & 12.5 \\
\hline
\end{tabular}


International Advanced Research Journal in Science, Engineering and Technology

Vol. 8, Issue 9, September 2021

DOI: 10.17148/IARJSET.2021.8926

\begin{tabular}{|l|l|l|}
\hline Total & 80 & 100 \\
\hline
\end{tabular}

(Source: Primary Data)

From the above data, $87.5 \%$ of students are preferring offline classes, $12.5 \%$ of students are prefer online classes.

The table: 5 Distribution of respondents based on the availability of internet/wi.fi connection at home.

\begin{tabular}{|l|l|l|}
\hline Category & Frequency & Percentage \\
\hline Yes & 66 & 82.5 \\
\hline No & 14 & 17.5 \\
\hline Total & 80 & 100 \\
\hline
\end{tabular}

Source: (Primary Data)

From the above graph shown the $82.5 \%$ of students are the availability of internet at home, $17.5 \%$ of students have no internet connection at home.

Table:6 Distribution of respondents based on the mode of an online class.

\begin{tabular}{|l|l|l|}
\hline Category & Frequency & Percentage \\
\hline Mobile phone & 75 & 93.8 \\
\hline Laptop & 5 & 6.2 \\
\hline Desktop & 0 & 0 \\
\hline Total & 80 & 100 \\
\hline
\end{tabular}

Source: (Primary Data)

The above table shows that $93.8 \%$ of students are using a mobile phone, $6.2 \%$ of students are used in a laptop.

Table:7 Distribution of respondents based on the satisfaction level of performance in online classes.

\begin{tabular}{|l|l|l|}
\hline Category & Frequency & Percentage \\
\hline Yes & 11 & 13.8 \\
\hline No & 37 & 46.2 \\
\hline May be & 32 & 40 \\
\hline Total & 80 & 100 \\
\hline
\end{tabular}

Source: (Primary Data)

From the above table, the $13.8 \%$ of the student satisfaction are not satisfied with their performance while $46.2 \%$, students of $40 \%$ may be satisfied or not satisfied in their performance in online classes

Table:8 Distribution of respondents based on concentration in the online class.

\begin{tabular}{|l|l|l|}
\hline Category & Frequency & Percentage \\
\hline Always & 15 & 18.8 \\
\hline Often & 16 & 20 \\
\hline Never & 9 & 11.2 \\
\hline Sometimes & 40 & 50 \\
\hline Total & 80 & 100 \\
\hline
\end{tabular}

Source: (Primary Data)

The above table shows the concentration of students in online classes are $18.8 \%$ are always and $20 \%$ are often $11.2 \%$ never, sometimes $50 \%$ are the respondents.

Table:9 Distribution of respondents based on time consumed for average learning.

\begin{tabular}{|l|l|l|}
\hline Category & Frequency & Percentage \\
\hline $1-3$ hours & 58 & 72.5 \\
\hline $3-5$ hours & 17 & 21.2 \\
\hline $5-7$ hours & 3 & 3.8 \\
\hline $7-10$ hours & 2 & 2.5 \\
\hline TOTAL & 80 & 100 \\
\hline
\end{tabular}

Source: (Primary Data)

The above table shows the average period of students learning 1-3 hours $72.5 \%$ and $3-5$ hours $21.2 \%, 5-7$ hours $3.8 \%$ and 7-10 hours $2.5 \%$.

Table:10 Distribution of respondents based on the effectiveness of remote learning.

\begin{tabular}{|l|l|l|}
\hline Category & Frequency & Percentage \\
\hline Not effective & 18 & 22.5 \\
\hline Slightly effective & 32 & 40 \\
\hline Moderate & 22 & 27.5 \\
\hline Very effective & 7 & 8.8 \\
\hline Extremely effective & 1 & 1.2 \\
\hline Total & 80 & 100 \\
\hline
\end{tabular}


Source: (Primary Data)

The above table shows the effectiveness of remote learning. $22.5 \%$ are not effective, $40 \%$ are slightly effective, $27.5 \%$ are moderate, $8.8 \%$ are very effective, and $1.2 \%$ extremily effective for students.

The tables:11 Distribution of respondents based on teacher's participation in online classes

\begin{tabular}{|l|l|l|}
\hline Category & Frequency & Percentage \\
\hline Not helpful & 10 & 12.5 \\
\hline Slightly helpful & 11 & 13.8 \\
\hline Moderate & 23 & 28.8 \\
\hline Very helpful & 31 & 38.7 \\
\hline Extremely helpful & 5 & 6.2 \\
\hline Total & 80 & 100 \\
\hline
\end{tabular}

Source: (Primary Data)

The above table shows the participation on online classes.12.5\% for not helpful,13.8\%slightliy helpful, $28.8 \%$ moderate, $38.7 \%$ very helpful, $6.2 \%$ extremely helpful for students.

Tables 12 Distribution of respondents based on experience while attending an online course.

\begin{tabular}{|l|l|l|}
\hline Category & Frequency & Percentage \\
\hline Boring & 40 & 50 \\
\hline Interesting & 19 & 23.8 \\
\hline Unable to understand & 21 & 26.2 \\
\hline Total & 80 & 100 \\
\hline
\end{tabular}

Source: (Primary Data)

The above table reveals that $50 \%$ of respondents are boring and $23.8 \%$ are interesting and $26.2 \%$ of respondents are unable to understand.

The table: 13 Distribution of respondents based on overall satisfaction.

\begin{tabular}{|l|l|l|}
\hline Category & Frequency & Percentage \\
\hline Very poor & 14 & 17.5 \\
\hline Poor & 28 & 35 \\
\hline Fair & 27 & 33.7 \\
\hline Good & 11 & 13.8 \\
\hline Very good & 0 & 0 \\
\hline Total & 80 & 100 \\
\hline
\end{tabular}

Source: (Primary Data)

The above table shows that $17.5 \%$ of respondents are very poor and $35 \%$ of respondents are poor and $33.7 \%$ of respondents are good and $13.8 \%$ are good.

Table:14 Distribution of respondents based on learning effectiveness.

\begin{tabular}{|l|l|l|}
\hline Category & Frequency & Percentage \\
\hline Very poor & 10 & 12.5 \\
\hline Poor & 33 & 41.25 \\
\hline Fair & 28 & 35 \\
\hline Good & 9 & 11.25 \\
\hline Very good & 0 & 0 \\
\hline Total & 80 & 100 \\
\hline
\end{tabular}

Source: (Primary Data)

The above table show that depicts that $12.5 \%$ of respondents of very poor and $41.25 \%$ of respondents are poor and $35 \%$ of respondents are fair and $11.25 \%$ of respondents are very good.

The table: Distribution of respondents based on clarity of the course content.

\begin{tabular}{|l|l|l|}
\hline Category & Frequency & Percentage \\
\hline Very poor & 12 & 15 \\
\hline Poor & 28 & 35 \\
\hline Fair & 27 & 33.7 \\
\hline Good & 13 & 16.3 \\
\hline Very good & 0 & 0 \\
\hline Total & 80 & 100 \\
\hline
\end{tabular}

Source: (Primary Data)

The above table depicts that $15 \%$ of respondents are very poor and $35 \%$ of respondents are poor and $33.76 \%$ of respondents are good and $16.3 \%$ of respondents are good and $0 \%$ of respondents are very good. 
International Advanced Research Journal in Science, Engineering and Technology

Vol. 8, Issue 9, September 2021

DOI: $10.17148 / I A R J S E T .2021 .8926$

Table:16 Distribution of respondents based on sufficient skills and knowledge to manage online learning

\begin{tabular}{|l|l|l|}
\hline Category & Frequency & \multicolumn{1}{c|}{ percentage } \\
\hline Strongly agree & 10 & 12.6 \\
\hline Agree & 17 & 21.2 \\
\hline Neutral & 36 & 45 \\
\hline Disagree & 17 & 21.2 \\
\hline Strongly disagree & 0 & 0 \\
\hline Total & 80 & 100 \\
\hline
\end{tabular}

Source: (Primary Data)

The above table shows that $12.6 \%$ of respondents are strongly agreeing and $21.6 \%$ of respondents are agreeing and $45 \%$ of student respondents are neutral and $21.2 \%$ of respondents are disagreeing and $0 \%$ of respondents are strongly agreeing. Table:17 Distribution of respondents on effective learning technique comparing traditional learning and online learning.

\begin{tabular}{|l|l|l|}
\hline Category & Frequency & Percentage \\
\hline Strongly agree & 8 & 10 \\
\hline Agree & 35 & 43.8 \\
\hline Neutral & 33 & 41.2 \\
\hline Disagree & 2 & 2.5 \\
\hline Strongly disagree & 2 & 2.5 \\
\hline Total & 80 & 100 \\
\hline
\end{tabular}

Source: (Primary Data)

The above table shows that $10 \%$ of respondents are strongly agreeing and $43.8 \%$ of respondents are agreeing and $41.2 \%$ of respondents are neutral and $2.5 \%$ of respondents disagree and $2.5 \%$ of respondents are strongly disagreed.

The table: 18 Distribution of respondents on pleasure on online learning

\begin{tabular}{|l|l|l|}
\hline Category & Frequency & Percentage \\
\hline Strongly agree & 8 & 10 \\
\hline Agree & 27 & 33.8 \\
\hline Neutral & 36 & 45 \\
\hline Disagree & 7 & 8.7 \\
\hline Strongly disagree & 2 & 2.5 \\
\hline Total & 80 & 100 \\
\hline
\end{tabular}

Source: (Primary Data)

The above table shows that $10 \%$ of students come under strongly agree and $33.8 \%$ of students are agreeing and $45 \%$ of students are neutral and $8.7 \%$ of students come under disagree and $2.5 \%$ of students are in strongly disagree.

Table 19 Distribution of respondents based on frustration and lack of interest in learning while being lockdown.

\begin{tabular}{|l|l|l|}
\hline Category & Frequency & \multicolumn{1}{|c|}{ percentage } \\
\hline Strongly agree & 20 & 25 \\
\hline Agree & 20 & 25 \\
\hline Neutral & 36 & 45 \\
\hline Disagree & 0 & 0 \\
\hline Strongly disagree & 4 & 5 \\
\hline Total & 80 & 100 \\
\hline
\end{tabular}

Source: (Primary Data)

The above table shows that $25 \%$ of student's respondents are strongly agreeing and $25 \%$ of student responses are agreed and $45 \%$ of students are neutral $0 \%$ of students are disagree and $5 \%$ of students are strongly disagree ing.

Table 20 Distribution of respondents based on the excess social media usage of students.

\begin{tabular}{|l|l|l|}
\hline Category & Frequency & percentage \\
\hline Strongly agree & 21 & 26.2 \\
\hline Agree & 29 & 36.2 \\
\hline Neutral & 27 & 33.8 \\
\hline Disagree & 3 & 3.8 \\
\hline Strongly disagree & 0 & 0 \\
\hline Total & 80 & 100 \\
\hline
\end{tabular}

Source: (Primary Data) 


\section{International Advanced Research Journal in Science, Engineering and Technology}

Vol. 8, Issue 9, September 2021

DOI: 10.17148/IARJSET.2021.8926

The above table depicts that 26.2 of student respondents are strongly agreeing are neutral and $3.8 \%$ of students are disagreeing and $0 \%$ of students are strongly disagreed.

The table: 21 Distribution of respondents based on a sense of isolation.

\begin{tabular}{|l|l|l|}
\hline Category & Frequency & \multicolumn{1}{|c|}{ percentage } \\
\hline Strongly agree & 10 & 12.5 \\
\hline Agree & 42 & 52.5 \\
\hline Neutral & 25 & 31.2 \\
\hline Disagree & 1 & 1.3 \\
\hline Strongly disagree & 2 & 2.5 \\
\hline Total & 80 & 100 \\
\hline
\end{tabular}

Source: (Primary Data)

The above table depicts that $12.5 \%$ of respondents are strongly agreeing and agree $52.5 \%$ and neutral $31.2 \%$ and disagree $1.3 \%$ and strongly disagree $2.5 \%$.

The table: 22 Distribution of respondents based on lack of communication skill.

\begin{tabular}{|l|l|l|}
\hline Category & Frequency & Percentage \\
\hline Strongly agree & 17 & 21.2 \\
\hline Agree & 35 & 43.8 \\
\hline Neutral & 23 & 28.8 \\
\hline Disagree & 3 & 3.7 \\
\hline Strongly disagree & 2 & 2.5 \\
\hline Total & 80 & 100 \\
\hline
\end{tabular}

Source: (Primary Data)

The above table shows depict strongly agree $21.1 \%$ of responses are agreed $43.8 \%$ are neutral $28.8 \%$ are disagreed $3.7 \%$ and strongly disagree $2.5 \%$.

The table: 23 Distribution of respondents based on the inability to focus on the screen.

\begin{tabular}{|l|l|l|}
\hline Category & Frequency & percentage \\
\hline Strongly agree & 16 & 20 \\
\hline Agree & 36 & 45 \\
\hline Neutral & 23 & 28.8 \\
\hline Disagree & 4 & 5 \\
\hline Strongly disagree & 1 & 1.2 \\
\hline Total & 80 & 100 \\
\hline
\end{tabular}

Source: (Primary Data)

The above table shows $20 \%$ of responses are strongly agreed, $45 \%$ are agreed neutral $28.8 \%$; $5 \%$ are disagreed and strongly disagree $1.2 \%$.

\section{FINDINGS}

$>\quad$ Most of the students are below 20 years old, $71.25 \%$

$>\quad$ Most of the student's respondents are undergraduate students.

$>\quad$ The majority of students prefer offline classes.

$>\quad$ Most of the students having a poor internet connection at home are, $83.5 \%$.

$>\quad$ The majority of students use mobile phones to access online classes.

Most of the students are not satisfied with their performance in online classes.

$>\quad$ The majority of students have a favorable atmosphere to attend online classes.

$>\quad$ The majority of students are not able to concentrate in online classes.

$>\quad$ Most of the students spend 1-3 hours per day for online classes

$>\quad$ Most of the respondents felt that remote learning is not effective.

$>\quad$ Poor -teacher students' relationship is there, in online classes

$>\quad$ The majority of the student feel boring while attending online classes.

$>\quad$ The overall satisfaction level is not satisfactory

Most of the students feel that the learning effectiveness of online classes is poor

$>\quad$ Most of the students have poor clarity of the course content 
DOI: $10.17148 /$ IARJSET.2021.8926

$>\quad$ Most of the students have neutral opinions on the timely response of graded assessment, quality, and helpfulness of professor's feedback, and on guidelines provided by the lectures before starting online classes

$>\quad$ Most of the students have sufficient skill and knowledge to manage online learning

$>\quad$ Most of the students feel online learning is not effective as traditional learning

$>\quad$ Most of the students agree that online tool is easy to use.

Most of the students have a neutral opinion on online learning is fun.

Most of the student agrees that they have frustration and lack of interest in learning while being lockdown.

$>\quad$ Most of the students agree they engage more time in social media while having online classes.

$>\quad$ Majority of students agrees online class creates a sense of isolation.

$>\quad$ The majority of students feel that an online class does not develop communication skills.

Most of the students agree that they are not able to focus on the screen.

\section{SUGGESTIONS}

Always create a personal connection with teache
$\quad$ Teachers should try to motivate their students.

$>\quad$ Teachers should help the student to maintain focus by providing certain tasks.

$>\quad$ Make funny and meaningful full discussion with students.

$>\quad$ Should take steps to encourage and engage students.

$>\quad$ Identifying and support struggling students.

$>\quad$ Conduct counseling sessions

$>\quad$ Motivate students to reduce their stress

$>\quad$ Provide proper social media awareness to students.

\section{CONCLUSION}

The study has examined the perception of the student towards online classes. The rise of covid-19 results in online classes. The negative impact of online learning courses students lose their interest in learning. They feel so much stress while having online learning. This is because of the ineffective e-learning method there are so many methods to adapt online classes effectively. The study also reveals that ineffective online learning. create problems such as lack of communication skill development and create a sense of isolation etc. The study concluded that the students and teachers should be ready to cope up with online learning. 